\title{
Survival and failure of Brazilian credit unions: an analysis of corporate governance characteristics
}

\author{
Sobrevivência e falha das cooperativas de crédito brasileiras: uma análise das \\ características de governança corporativa
}

\begin{abstract}
We aim in this paper to understand the link between corporate governance characteristics and the discontinuity of Brazilian credit unions, investigating if these characteristics affect their strategy of exiting the market. The information on the discontinuity was collected at the Brazilian Central Bank, and corporate governance variables, such as duality and board size, for instance, were withdrawn from bylaw then-current in 2016. The final sample comprises 44 discontinued and 1,006 continued credit unions. Using both quantitative and qualitative approaches, we perform tests to verify the statistical differences between those groups. Despite finding statistical differences in some of the corporate governance characteristics, it is noteworthy that age and size seem to have a greater effect on the discontinuity. Moreover, apparently, the cost of compliance imposed by regulatory bodies might influence the credit unions in different ways. This suggests possibilities for further research on this topic, such as the role of member heterogeneity on corporate governance structures and discontinuity.
\end{abstract}

Keywords: Credit unions; corporate governance; discontinuity.

\section{Resumo}

Este trabalho teve como objetivo compreender a relação entre as estruturas de governança corporativa e a descontinuidade das cooperativas de crédito brasileiras, investigando se estas características afetam sua opção de saída do mercado. A informação sobre a descontinuidade foi coletada junto ao Banco Central do Brasil, e as variáveis de governança corporativa, como a dualidade e o tamanho do conselho, por exemplo, foram obtidas nos estatutos sociais vigentes no ano de 2016. A amostra final compreendeu 44 cooperativas descontinuadas e 1.006 continuadas. Utilizando abordagens quantitativas e qualitativas, testes foram realizados para verificar diferenças estatísticas entre os dois grupos. Apesar de algumas diferenças estatísticas terem sido identificadas, é mais notável que idade e tamanho exercem mais efeito sobre a descontinuidade. Além disto, o custo de compliance imposto pela regulação aparenta exercer influência ambígua nas cooperativas de crédito. Os resultados sugerem novas pesquisas neste tópico, como o papel da heterogeneidade dos membros sobre as estruturas de governança e a descontinuidade das cooperativas de crédito.

Palavras-chave: Cooperativas de crédito; governança corporativa; descontinuidade.

Bruno José Canassa ${ }^{\mathrm{I}}$, Davi Rogério de Moura Costa ${ }^{\mathrm{II}}$, Mateus de Carvalho Reis Neves ${ }^{\mathrm{III}}$

${ }^{\text {I } U n i v e r s i d a d e ~ d e ~ S a ̃ o ~ P a u l o, ~ b j c a n a s s a @ f e a r p . u s p . b r ~}$

${ }^{\text {II }}$ Universidade de São Paulo, drmouracosta@gmail.com

${ }^{\text {III }}$ Universidade Federal de Viçosa, mateus.neves@ufv.br 


\section{Introduction}

According to the Central Bank of Brazil (CBB), in recent years the assets of Brazilian credit unions increased at a rate of $15.2 \%$ a year, around three times the rate of other financial institutions (5.4\%) (BCB, 2017a). Despite this, the number of credit unions in Brazil is diminishing at a rate of $3.4 \%$ a year, possibly by a process of mergers (BAUER; MILES; NISHIKAWA, 2009; SOARES; COSTA, 2018). The study of mergers in Brazilian credit unions offers a field to understand their discontinuity. For instance, we can explore which factors lead them to end their activities. We can see this type of research in several models of organizations such as pointed by Josefy et al. (2017), which provide a framework to investigate discontinuity. However, their paper does not explore why and how discontinuity occurs in credit unions.

In this context, for Cook (1995) and Cook and Burress (2009), any cooperative organization follows a life cycle. For them and Bauer, Miles and Nishikawa (2009), when the "financial health" of a cooperative start to decrease, the board of directors, acting on behalf of the members, must choose a strategy aiming to fix problems originated by the "vaguely defined" ownership rights. For instance, they need to decide whether to liquidate, continue, or shift the characteristics of the rights of control. Any alternative has implications that change the corporate governance structure.

Some papers demonstrate the link between discontinuity and performance (a possible proxy for "financial health"). Carvalho et al. (2015) determine the financial indicators that affect the longevity of credit unions. In addition, Canassa and Costa (2018) found that the performance of credit unions before discontinuity is worse than those cooperatives that have survived. Despite this, neither paper explores relations with the corporate governance structures albeit its importance. Daily and Dalton (1994a) and Wang and Hsu (2013) note that characteristics of governance structures - such as board composition, size, independence, and CEO-duality — have a significant impact on bankruptcies.

Then, in this paper, we shed light on the link between corporate governance characteristics and discontinuity of Brazilian credit unions. Overall, the literature neglects this topic. We use a sample of discontinued credit unions to identify if characteristics of governance structure have influenced the strategy for exiting the market. For this, we conducted an exploratory analysis of the characteristics noted as prominent in corporate governance for cooperatives. With our analysis, we expect to start a research agenda that assists in better understanding the determinants of the mortality of Brazilian credit unions.

The sequence of this paper includes a theoretical framework containing a brief overview of the literature and the case of discontinuities of Brazilian credit unions, as well as the theoretical foundations for corporate governance in those organizations. Then, we explain the data and methods utilized. Finally, we present the results and point out some concluding remarks and contributions.

\section{Theoretical Framework}

In the last few decades, studies have shown the impact of corporate governance characteristics on discontinued firms. Early works in this theme found that some traits such as CEO duality and the quality of the board act as determinants for bankruptcy in investor-oriented firms (DAILY; DALTON, 1994a, 1994b). The authors and other works such as Sundaramurthy and Lewis (2003) suggest a continuous cycle between corporate governance structures and performance. According to them, performance is a determinant of the discontinuity of activities. In other words, an organization whose performance is continually poor cannot properly provide a return to the investment of its owners. This creates other problems and reaches insolvency as the apex. Thus, the owners choose to discontinue the firm.

Since then, several works have pointed out the important role of ownership and corporate governance in the process that leads to the end of activities. According to Darrat et al. (2016), Wilson, Wright, and Scholes (2013) and Wang and Hsu (2013), board composition and CEO characteristics are determinants or at least imply a risk of discontinuity. These studies have 
addressed various types of organizations, including investor-oriented and family firms, along with commercial banks. However, although credit unions in all countries have undergone a process of discontinuity (BAUER; MILES; NISHIKAWA, 2009), the role of corporate governance in this process for this type of organization has not yet been investigated.

The next sections present the fundamental concepts for understanding the discontinuity of Brazilian credit unions. First, we present a definition of discontinuity, some data regarding the Brazilian case and the potential motives related to corporate governance that leads members to opt to discontinue the cooperative. Then, we explore the corporate governance characteristics for cooperative organizations.

\subsection{Discontinuity and the case of Brazilian credit unions}

Josefy et al. (2017) reviewed the empirical literature on firm discontinuity, pointing out many motives for discontinuance. Among others, they cited stages of development, industrial organization, and corporate governance. In this paper, we use a definition of discontinuity set out by Josefy et al. (2017): the end of the current ownership of a firm. This definition is important because discontinuity cannot be intrinsically associated with ceased operations or insolvency. For instance, in a merger between two companies their operations might continue, but under new ownership and belonging to another new firm. Also, an insolvent firm would discontinue its operations by the end of its ownership, forced or by the option of its owners, and not just by the insolvency itself.

Mergers and acquisitions are important in the analysis of discontinuance of Brazilian credit unions. In fact, in recent years, the CBB has been stimulating those cases among credit unions. Apparently, it aims to promote gains derived by economies of scale and create competitiveness in the banking sector (BCB, 2017b). According to Soares and Costa (2018), 228 mergers among Brazilian credit unions occurred from 2008 to 2015. However, it was not the only reason. Canassa and Costa (2018) and Soares and Costa (2018) found that the end of activities, chosen by the members themselves, was also an important reason for discontinuity.

Theoretically, Cook (1995) and Cook and Burress (2009) point out that cooperatives follow a life cycle based on their "financial health". For them, "financial health" reflects the financial condition of members and the cooperative organization itself. Each phase of the life cycle has its own characteristics, such as the growth of members' heterogeneity that suggest adjustments of corporate governance mechanisms. According to the authors, when the "financial health" of both the cooperative and members start to decrease, the management and members must choose a strategy in terms of better allocation of ownership rights. In this way, mergers or acquisitions are possible choices, for example. Therefore, the presumed low "financial health" might be a determinant factor in the discontinuity of cooperatives, if we consider that it affects the current characteristics of ownership, operation, and control.

Some empirical studies investigated the role of "financial health" in the discontinuity of credit unions. Looking for determinants, Carvalho et al. (2015) found financial indicators as determinants for longevity in credit unions. Canassa and Costa (2018) found that discontinued credit unions, such as the acquired, were operating at a level below the continued credit unions. Bauer, Miles, and Nishikawa (2009) point out the low level of efficiency in incorporated credit unions. Besides "financial health", Barron, West, and Hannan (1994) investigate socioeconomic reasons and found factors such as age, size, and competition to be determinants of the mortality of credit unions.

Although in theory the allocation of ownership rights influences the stages of the cooperative life cycle (COOK, 1995; COOK; BURRESS, 2009) and the existence of a cooperative (CHADDAD \& ILIOPOULOS, 2013), empirically there are few papers investigating the effect of corporate governance characteristics on credit union failure. There are studies of other types of organizations; their results suggest that corporate governance factors have been affecting the continuity of organizations. Assuming this as a hypothesis, and considering that corporate governance and performance are endogenous (SUNDARAMURTHY; LEWIS, 2003), in this paper we explore the corporate governance characteristics of discontinued credit unions. 


\subsection{Corporate governance in cooperative organizations}

Cooperative organizations, such as the credit unions, are companies whose owners are also users of its products and services. The members' ownership rights become vaguely defined as cooperatives start to grow, and the relevant information to make decisions is located in many individuals within the organization. According to Cook (1995), due to the characteristics of property rights, the life cycle of cooperatives presents five problems: horizon, portfolio, free-rider, control, and influence costs. They are challenges to the management of these companies.

Chaddad and Cook (2004) described different models of cooperatives, considering the characteristics of residual rights. Additionally, Chaddad and Iliopoulos (2013), using a set of peculiarities of rights of control, propose a range of governance structures for cooperatives. Iliopoulos (2015) connected these two papers. In his investigation, the author uses two terms: ownership and governance model. The former separates the models according to the capitalization of the cooperative, and the latter classifies the model as a function of allocation of authority. In this paper, we agree with Iliopoulos (2015). We also consider that capitalization mechanisms and allocation of authority are important in studying the governance of cooperative organizations.

The regulator of Brazilian credit unions forbids investor capital in their ownership structure. That is, they cannot receive capital from investors, even if they are members. In this way, there are only traditional cooperatives, if we consider the mechanisms of capitalization or ownership models in these organizations. This means we can analyze, for a while, just characteristics of governance models or formal authority allocation and its effect on the discontinuity of credit unions.

Considering the agency problem in organizations as a baseline for studying corporate governance, the literature on this topic stresses the board of directors as the apex in representing the owners' objective function. Becht, Bolton, and Röell (2003), for instance, highlight its importance as an alternative in solving the collective action problem. Adams, Hermalin, and Weisbach (2010) describe their roles and characteristics. A critical responsibility of this governance structure is to monitor the managers. Therefore, its size becomes a strategic choice due to the effort expended by members. As the size of the board increases, measured by member number, the marginal effort of the average member might be reduced given the free-rider problem or shirking. Thus, in this paper, we investigate the size of the board of directors.

Alchian and Demsetz (1972), Aghion and Tirole (1997) and Aghion, Dewatripont and Rey (2004) point out other characteristics important in studying governance: the allocation of control, that is, delegation as an important strategy to solve problems arising from collective ownership. Then, we consider not only the board but also all decision bodies that comprise an organizational architecture. Like Chaddad and Iliopoulos (2013) and Costa, Chaddad, and Azevedo (2012), we investigate what bodies comprise the governance structure of Brazilian credit unions. This information is helpful in understanding how the delegation of formal authority occurs in cooperatives.

According to Chaddad and Iliopoulos (2013), there are three different models in cooperative organizations: traditional, extended traditional, and managerial and corporate. The difference between them is a function of the presence or absence of the bodies in organizational architecture. In particular, in cooperatives from South America the authors have reported only two models: traditional and extended traditional. The first one encompasses three decision bodies: General Assembly, Board of Directors, and the Supervisory Board. It differs from the extended model because the latter has a group of executive directors hired or elected by members of the board. Therefore, we shall verify the governance structure and the presence of committees.

Fama and Jensen (1983) highlighted the separation of the decision process as a determinant of the survivability of companies. It is recommended if a company is complex and if its ownership structure is dispersed. The concentration of decision control and management is better if the firm has the opposite characteristics. Several researchers have explored this, for example, Brickley, Coles, and Jarrell (1997), Goyal and Park (2002), and Bhagat and Bolton (2008). Using the concept of CEO duality, some authors have highlighted the benefits of concentration; others have pointed out gains from separation. Therefore, this debate is no longer consolidated. Then, we use this variable in order to assess its impact on cooperatives. 
The independence of the manager means that the board assumes its role and delegates to the CEO the formal rights of control of the company. Adams, Hermalin and Weisbach (2010) described its roles as disciplinary and advisory in relation to management. Becht, Bolton, and Röell (2003) and Hermalin and Weisbach (1998) have shown manager independence as an important factor in the performance of firms. That is, firm performance is better if the board focuses on its role and managers on the operation of the company.

\section{Data and Methods}

By the explorative nature of this paper, our approach is both quantitative and qualitative. The use of both approaches is due to the variables constructed because some allow inferences from statistics such as means and medians, in the quantitative case, and others from the description of characteristics, for the qualitative case (RYAN; SCAPENS; THEOBALD, 2002). We gathered the data used to construct the corporate governance variables in this study from the then-current bylaw of 1,050 first-level Brazilian credit unions for the year 2016. The CBB made those bylaws available for this analysis. Moreover, we constructed other variables used in this study through open data available on the websites of CBB and the Brazilian Institute of Geography and Statistics.

We construct a dummy to represent the continuity or discontinuity of a credit union; this information was available in monthly reports accessed on the CBB website. Using the definition of discontinuity, we consider a credit union as discontinued if it left the register, without returning within a few months in the same year. This verification was important because a credit union may temporarily stop its activities and return to normal operations later, and avoid the possibility that we classify a credit union as discontinued when it only stopped its activity briefly. After both conditions, that is, availability of bylaws and discontinuity condition, we found 44 discontinued credit unions. This means that $4.2 \%$ of the credit unions ended their activities in that year.

Considering the exploratory nature of this study, we describe the characteristics of corporate governance of interest and others related to the literature on the failure of firms. This additional analysis helps us to determine other possible explanations for the discontinuity of credit unions. For example, the effects of size and age on credit union mortality as pointed out by Barron, West, and Hannan (1994) and organizational and industrial organization characteristics mentioned by Josefy et al. (2017). We use the amount of equity as a measure of size of the credit unions; the years of existence as a proxy for age; competition in its geographic region, the type of association (common bond) and the type of operations (more or less complex) allowed by the CBB as proxies for the organizational and industrial characteristics.

As we focus on the corporate governance characteristics in the paper, we describe these characteristics considering two groups: continued and discontinued credit unions. Although this first analysis does not aim to find determinants, it is important to situate the distribution of characteristics among groups in order to add more information in the further analysis. For some characteristics, such as board size and presence of other committees, the process of identification of this information in the bylaws was simple. The document is clear in this respect. However, we must assume the number of members is the maximum number that could be elected. Although this is not necessarily the real number of directors elected, it is the potential number chosen by the members. In addition, we consider two types of governance models, as described by Chaddad and Iliopoulos (2013) for cooperatives in South America. We name "expanded model" when the credit union had a Board of Directors and a group of executive directors, and a "traditional model" when the cooperative had just a Board of Directors or a group of executives. The duality was identified when the bylaw makes clear that the president of the credit union, elected in general assembly, assumes the position of principal director. In cases where this is not clear, duality was not considered. Finally, we measure the independence of the board as the ratio of the number of board members that the bylaws note as having no executive function to the number of board members potentially elected.

We conduct statistical tests to verify possible differences in the variables (governance or controls) between the groups of discontinued and continuing credit unions. For variables characterized as quantitative, we performed means and medians tests among the groups, with both 
tests have as a null hypothesis the equality of the means (or medians). The means test is based on the $t$ statistic (BUSSAB; MORETTIN, 2002), and the median test in the Pearson chi-square (CONOVER, 1999). For the qualitative variables, we performed Fisher's exact test to detect differences in the frequency distribution of the variables for the groups of continuing and discontinued credit unions. Fisher's exact test uses the F statistic and has a null hypothesis of equality between the groups. The option for Fisher's exact test is due to the presence of categories with less than five observations (BUSSAB; MORETTIN, 2002).

\section{Results and Discussion}

Table 1 on next page shows the frequency of continued and discontinued credit unions considering the size measured by total equity (E). In parentheses we show the proportions of this frequency.

The results indicate size as an important variable, as we can note that the majority of credit unions that ceased activities in 2016 were small organizations. Around $56.8 \%$ ( 25 of 44 cases) of discontinued cooperatives had less than $\mathrm{R} \$ 1.6 \mathrm{~m}$ in equity. This result follows Barron, West and, Hannan (1994). In other words, small credit unions do not seem to survive local competition with banks or another credit union. Then, the members choose to end the company's activities. If members consider the expected value of the transaction with a credit union, we can infer that members choose to discontinue their structure, expecting better benefits from contracts with other organizations ${ }^{1}$, which could be credit unions or not. In addition, if an individual member continues as member in another credit union, it explains an acquisition or fusion; and it may be an explanation for the huge rate of growth of member numbers (an annual increase of $10.9 \%$ between 2010 and 2015 according to data from the Organization of Brazilian Cooperatives) in Brazilian credit unions in the last decade.

Table 1 - Frequency of discontinuance by size

\begin{tabular}{cccc}
\hline & $\begin{array}{c}\text { Larger Credit Unions } \\
(\mathrm{E} \geq 11.5)^{\mathrm{a}}\end{array}$ & $\begin{array}{c}\text { Average Credit Unions } \\
(11.5>\mathrm{E} \geq 1.65)^{\mathrm{a}}\end{array}$ & $\begin{array}{c}\text { Smaller Credit Unions } \\
(\mathrm{E}<1.65)^{\mathrm{a}}\end{array}$ \\
\hline $\begin{array}{c}\text { Discontinued } \\
\text { Continued }\end{array}$ & $10.4 \%)$ & $18(3.4 \%)$ & $25(9.5 \%)$ \\
\hline $\begin{array}{c}\text { Fisher's exact test (p- } \\
\text { value): }\end{array}$ & $261(99.6 \%)$ & $507(96.6 \%)$ & \\
\hline & o.0oo*** & & \\
\hline
\end{tabular}

On the Table 2 we display, by group (continued or discontinued), the age of credit unions. This information, according to Barron, West and Hannan (1994), is important because it contributes to understanding credit union mortality.

Table 2 - Frequency of discontinuance by age

\begin{tabular}{cccc}
\hline & $\begin{array}{c}\text { Mature Co-ops } \\
(\text { Age }>28)\end{array}$ & $\begin{array}{c}\text { Intermediate Co-ops } \\
(28>\text { Age }>15)\end{array}$ & $\begin{array}{c}\text { Young Co-ops } \\
(15>\text { Age })\end{array}$ \\
\hline Discontinued & $3(1.3 \%)$ & $11(2.1 \%)$ & $30(10.4 \%)$ \\
Continued & $234(98.7 \%)$ & $513(97.9 \%)$ & $259(89.6 \%)$ \\
\hline Fisher's exact test (p-value): & o.ooo $^{* * *}$ & &
\end{tabular}

We found that young credit unions are more likely to end their activities compared to similar (in terms of type of operations, more details to follow) but older credit unions. A possible explanation is size. In general, young credit unions are small. These credit unions probably face competition with consolidated financial institutions and fail to offer services to their members, who 
choose to end the credit union. Although we found a moderate correlation (0.27) between size and age, further research must be conducted on this issue.

Along with Canassa and Costa (2018), we consider the possibility that these credit unions may have been performing poorly before discontinuity. Then, financial health inhibits these organizations from reaching the stage where corporate governance gains importance, with increasing heterogeneity among members and the need to strengthen property rights.

Considering size and age together, the discontinuity process might be a dysfunction of the regulation process exercised by $\mathrm{CBB}$. The regulator has required specific structures for credit unions, and this can negatively affect its operating costs. If these organizations are not ready to assume new (and higher) costs, then this can explain the choice of members and managers to end activities.

Another potential explanation is the regulation from second-level credit unions. That is, a federate co-op, created by local credit unions to coordinate their activities as a group. Together, these credit unions start to act as a system ${ }^{2}$. Then, they create rules for each credit union in the system. Therefore, it is possible that these rules, viewed as internal regulation, are increasing regulatory costs. We suggest further research on this topic.

Like Josefy et al. (2017) and Barron, West and Hannan (1994), we explore in this study the potential effect of geographic region on the likelihood of discontinuance of credit unions. Table 3 on next page shows the distribution of credit unions that finished their activities in each Brazilian region. It is important to point out a concentration of credit unions in the richest regions: Southeast and South. Almost $80 \%$ have a base in these regions.

Table 3 - Frequency of discontinuance by region

\begin{tabular}{ccc}
\hline Region & Discontinued & Continued \\
\hline North & $5(10.4 \%)$ & $43(89.6 \%)$ \\
Northeast & $6(6.7 \%)$ & $84(93.3)$ \\
Southeast & $14(2.8 \%)$ & $484(97.2 \%)$ \\
South & $15(4.5 \%)$ & $317(95.5 \%)$ \\
Central-West & $4(4.9 \%)$ & $78(95.1 \%)$ \\
\hline
\end{tabular}

\begin{tabular}{cc}
\hline Fisher's exact test (p-value): & $0.057^{*}$ \\
\hline & Note: ${ }^{*}$ Significant at $10 \%$.
\end{tabular}

Considering this concentration, the Southeast region has the lowest discontinuance rate of credit unions in Brazil. In other words, the relation between total and discontinued credit unions is only $2.8 \%$. Despite the great number of organizations, the competition makes these credit unions better than others in another region.

On the other hand, it is remarkable that the Northeast and North regions, with few credit unions, have the highest discontinuity rates. The North region has, at least, twice the rate of mortality compared to any other region. Perhaps it represents the developing economic system of that region. That is, a poor region impacts on few credit unions and less structured companies. If this is the case, maybe they are more susceptible than other credit unions, for instance those located in south, to ending their activities.

Another potential explanation lies in the action of CBB, which has been encouraging acquisitions or mergers among credit unions in the South and Southeast. According to the regulator, this is to stimulate competition and consolidation of credit unions.

For a better understanding of the distribution of size and age in discontinued credit unions for each region, we present Table 4. The percentage number in the table represents a proportion of, for instance, small credit unions of the region in the group of smallest discontinued credit unions (Table 1). The same applies for young credit unions. 
Table 4 - Frequency of discontinued credit unions by region, size and age

\begin{tabular}{ccc}
\hline & Smaller Credit Unions & Young Credit Unions \\
\hline North & $3(12.0 \%)$ & $5(16.7 \%)$ \\
Northeast & $4(16.0 \%)$ & $5(16.7 \%)$ \\
Southeast & $9(36.0 \%)$ & $7(23.3 \%)$ \\
South & $8(32.0 \%)$ & $12(40.0 \%)$ \\
Central-West & $1(4.0 \%)$ & $1(3.3 \%)$ \\
\hline
\end{tabular}

The South and Southeast region have a higher frequency of credit unions (small and young) that ended their activities in 2016. This may be evidence of a strategy adopted by credit unions, which aim to become larger. We can view it as an answer to the regulators - CBB or system recommending mergers among credit unions in these regions.

On the other hand, in the North and Northeast regions, the proportion of young and small credit unions that have ceased activities is not high. A potential explanation can be related to the characteristics of these companies. As credit unions are small and young, they are likely unable to compete with public and private banks, especially with the public banks that have high capillarity in these regions. Perhaps they do not have enough to compete in the financial system. In this way, the incumbents do not treat them as an entrant in the market.

Table 5 shows the results according to the category that represents the type of operations permitted by the CBB: "plena", "clássica", and "capital e empréstimo". The "clássica" credit unions are those that operate loans and investments on behalf of their members; "capital e empréstimo" are types of credit unions that only operate loans and savings to the owners; in general, the members must continually capitalize their organization. A "plena" credit union differs from the "clássica" because they carry out operations like cambial exchanges. This type is more similar to the commercial banks than other credit unions. According to CBB, this classification represents different levels of risk. In order, "plena" is riskier than "clássica", which is riskier than "capital e empréstimo".

Table 5 - Frequency of discontinuance by type of operations

\begin{tabular}{cccc}
\hline & "Plena" & “Clássica" & "Capital e Empréstimo" \\
\hline $\begin{array}{c}\text { Discontinued } \\
\text { Continued }\end{array}$ & o (o.o\%) & $36(4.4 \%)$ & $8(4.1 \%)$ \\
\hline $\begin{array}{c}\text { Fisher's exact test (p- } \\
\text { value): }\end{array}$ & $33(100.0 \%)$ & $784(95.6 \%)$ & $189(95.9 \%)$ \\
\hline
\end{tabular}

Although the type "clássica" is more frequent (36) among discontinued credit unions, it represents only $4.4 \%$ of the total of "clássica" existing in 2016. This rate is similar to the proportion of "capital e empréstimo" that ended activities (4.1\%), in a total of "capital e empréstimo". As risk is an important explanatory factor for failure of organizations, and the results partially do not corroborate it, we strongly recommend further studies to check if it is a determinant factor in cooperatives. For now, it appears to not influence discontinuity of credit unions.

New studies must verify if the types created by CBB represent the expected level of risk of these organizations. For instance, if the level of risk of "capital e empréstimo" is lower than "clássica", why do they reflect similar rates of discontinuance? In other words, "capital e empréstimo" credit unions, which have low risk in their operations, should have a lower frequency of discontinuities.

There is another aspect of credit union regulation that we should consider. To stimulate an expansion of access to financial markets, the CBB created regulations to facilitate the entrance of new members in credit unions. In this way, the credit unions are separated in groups: free entry, rural credit and mutual. 
A free entry credit union differs from the other groups because any person can become a member, since it is located in the geographic area of operation of the credit union. A rural credit union is characterized as a type of credit unions where the members are exclusively farmers. Mutuals are a large group, because they encompass all other types of credit union. The main difference between a free entry and a mutual credit union is that the first does not require common ties among its members. This is mandatory in a mutual credit union. Table 6, on next page, shows the frequency of these types of associations between the groups of credit unions.

The main result is the frequency of discontinuities in the credit unions composed of farmers. Although it is the smallest group $(19.1 \%$, or 201 of 1,050$)$ in the total credit unions group, this type of cooperative represents $38.6 \%$ (17 of 44 ) of the total number that ended their operations in 2016. According to Soares and Costa (2018), these credit unions were acquired by others.

As members of rural credit unions are farmers, this type of organization must provide them services related to rural credit. It is an important public policy in Brazil. In general, the government regulates this contract, specifically the interest rate. Perhaps rural credit unions are not offering services to match the interests of their members, who find them instead in a commercial bank.

Table 6 - Frequency of discontinuance by type of association (common bond)

\begin{tabular}{cccc}
\hline & Free Entry & Rural Credit & $\begin{array}{c}\text { Mutual Credit and other } \\
\text { types }\end{array}$ \\
\hline Discontinued & $8(2.6 \%)$ & $17(8.5 \%)$ & $19(3.5 \%)$ \\
Continued & $299(97.4 \%)$ & $184(91.5 \%)$ & $523(96.5 \%)$ \\
\hline $\begin{array}{c}\text { Fisher's exact test (p- } \\
\text { value): }\end{array}$ & $0.016^{* *}$ & \\
\hline \multicolumn{4}{c}{ Note: ${ }^{* *}$ Significant at $5 \%$}
\end{tabular}

This situation might be affecting the rentability of credit unions and stimulating them to migrate to other groups. For example, they are making agreements with free entry credit unions and becoming just one company ${ }^{3}$. However, considering that the rural sector is one of the most important sectors in Brazil economically, we suggest further analysis.

Table 7 shows the results for the corporate governance characteristics of the discontinued group of credit unions. It contains the results regarding size of the board.

Table 7 - Descriptive analysis of board size by continuity

\begin{tabular}{cccc}
\hline & All & Discontinued & Continued \\
\hline Mean & 8 & 8 & 8 \\
Median & 7 & 7 & 7 \\
Variance & 9 & 10 & 9 \\
Max & 26 & 22 & 26 \\
Min & 2 & 2 & 2 \\
\hline Mean test (p-value): & 0.436 & & \\
Median test (p-value): & 0.280 & & \\
\hline
\end{tabular}

We found that both types of credit unions, in operation (continued) or failure (discontinued), have eight members (mean) on the board. The same occur to the median with seven members. The tests confirm the similarity of this characteristic. That is, they do not differ; apparently, this characteristic does not affect the failure or continued operation of credit unions. 
However, if we link this result with age and size of credit unions it gives us some insights. Maybe a discontinued credit union (small and young) was affected by rules of governance created from CBB. For example, to attend a rule, even though their characteristics suggest other choices, credit unions are obliged to choose a high number of members. It affects its cost of collective decision-making. In addition to that, there is a minimum size required by law, and this can overload the governance costs.

Table 8 shows the frequency of existence of other committees in the continued and the discontinued credit unions.

Table 8 - Frequency of discontinuance by existence of other committees

\begin{tabular}{ccc}
\hline & Predict Committee & Don't Predict Committee \\
\hline Discontinued & $13(6.4 \%)$ & $31(3.7 \%)$ \\
Continued & $189(93.6 \%)$ & $817(96.3 \%)$ \\
\hline Fisher's exact test (p-value): & $0.062^{*}$ & \\
\hline
\end{tabular}

Looking at bylaws of credit unions, we tried to find if the society imposes a possibility of other committees besides the board of directors and supervisor committee. For instance, a credit committee or election committee. Despite the cost, we consider this other committee as a good governance practice. It can provide greater monitoring, i.e., less information asymmetry between principal and agent.

We found that the presence of other committees is more frequent in the group of discontinued credit unions. Also, this difference is statistically significant between the two groups. This result disagrees with the hypothesis linked to improvements in monitoring. However, there may be a relation with the size and age of credit unions and the cost linked to the process of governance. An additional committee might affect costs and undermine its operations.

A subsequent analysis could examine whether credit unions with other committees have greater members' heterogeneity. Perhaps, despite being small and young credit unions, their members are heterogeneous, and this affects their costs and their life cycle becomes shorter. If this is the case, we have a result that can corroborate Cook (1995) ${ }^{4}$.

We highlight in Table 9 the frequency of models of governance between the groups of credit unions. As described before, in Brazil there are only two types of models: expanded and traditional. Although the last one is more prevalent, the BCB is enforcing, through regulation, the first for some credit unions.

Table 9 - Frequency of discontinuance by model of governance

\begin{tabular}{ccc}
\hline & Expanded & Traditional \\
\hline Discontinued & $20(3.3 \%)$ & $24(5.4 \%)$ \\
Continued & $588(96.7 \%)$ & $418(94.6 \%)$ \\
\hline Fisher's exact test (p-value): & $0.061^{*}$ & \\
\hline
\end{tabular}

Note: *Significant at $10 \%$

We found that credit unions that have chosen the traditional model of governance stopped their operations more frequently. Perhaps these credit unions are in the primary stages of their life cycle. The results met theoretical expectations. Credit unions with smaller governance models tend to have less monitoring over their agents, as well as a lower level of specialization in management. Nevertheless, we cannot affirm that this is the determinant factor in the failure of credit unions. 
Another possible explanation is related to the size of credit unions. A preliminary analysis found a concentration of credit unions that chose the expanded model in the quartile of bigger credit unions (it is related with $\mathrm{BCB}$ regulation process). On the other hand, smaller cooperatives have chosen the traditional model.

We present the results for CEO duality in Table 10. In this case, we consider a duality if the CEO and chairman are the same person. We searched each by-law to check if this is mandatory (de jure) or not. We recognize the possibility that more credit unions have duality, although the by-law does not point to this (de facto duality).

Table 10 - Frequency of discontinuance by duality

\begin{tabular}{ccc}
\hline & CEO duality allowed & CEO duality not allowed \\
\hline Discontinued & $19(4.4 \%)$ & $25(4.1 \%)$ \\
Continued & $415(95.6 \%)$ & $591(95.9 \%)$ \\
\hline Fisher's exact test (p-value): & 0.458 & \\
\hline
\end{tabular}

The frequency of duality is lower in the group of discontinued credit unions than its absence. This is an unexpected result. Theory indicates that the survival of complex organizations with dispersed ownership, such as cooperatives, is related to the separation of ownership and management (BRICKLEY; COLES: JARRELL, 1997). One possible explanation is the same as some of the previous items: governance structures that are larger than indicated for the current stage of the credit union's life cycle.

Furthermore, another important factor related to duality is the fact that the CBB has imposed the separation between the manager and functions in monitoring bodies, such as the Board of Directors. In this case, the CBB imposes this rule on large cooperatives, such as "plenas" and large "clássicas". We may infer that the size influences more than the existence of duality or otherwise in the continuity of credit unions.

However, like the other results for corporate governance, they are still little accentuated for robust inferences. In fact, in this case the Fisher's exact test not points to whether evidence of differences between the groups. This leads to the ambiguity of results found in the recent empirical literature on duality, which found positive and negative possible outcomes for this phenomenon in organizations 5 .

Finally, Table 11 contains the results for the independence of the board. As noted, values close to zero indicate a greater presence of members of the boards with executive functions.

Table 11 - Descriptive analysis of independence of the board by continuity

\begin{tabular}{cccc}
\hline & All & Discontinued & Continued \\
\hline Mean & 0.607 & 0.561 & 0.609 \\
Median & 0.667 & 0.571 & 0.667 \\
Variance & 0.060 & 0.069 & 0.060 \\
Max & 0.950 & 0.950 & 0.909 \\
Min & 0.000 & 0.000 & 0.000 \\
\hline Mean test (p-value): & 0.103 & \\
Median test (p-value): & $0.029^{* *}$ &
\end{tabular}

Independence is greater in continued cooperatives, corroborating what is expected by theory (BECHT; BOLTON; RÖELL, 2003; HERMALIN; WEISBACH, 1998). Unlike the other indicators, 
independence does not necessarily increase the costs associated with the governance structure of the credit union. Therefore, the results may be highlighting that the independence of the main monitoring body over the agents effectively improves the chances of survival of the credit union. However, it is necessary to deepen the research for further conclusions on this point - the mean tests do not reject the difference between the groups.

The independence of the board also points to the existence of professional executives in the continuing credit unions. As pointed out by Carvalho et al. (2015), the absence of professionalism is a common factor found in Brazilian credit unions, and is a possible explanation for the process of discontinuance. However, professionalism is a complex variable, and more conclusions on this topic requires further analysis.

\section{Final Remarks}

The main purpose of this study was to shed some light on the role of governance structures found in Brazilian credit unions and their relation to their survival, a topic already discussed in other types of organizations (JOSEFY et al., 2017), but not yet investigated in the recent scenario of discontinuities found in Brazilian credit unions.

According to the cooperative life cycle theory (COOK, 1995), cooperatives have their activities and survival dictated by their "financial health". When the cooperative's "financial health" declines, the members may opt for a type of exit. Previously, internal aspects of the cooperative, such as the allocation of property rights and the assembly of governance structures, were modified as problems such as membership heterogeneity increased. Thus, governance theoretically is important for the survival of cooperatives.

We started with a sample of 1,050 Brazilian credit unions, and, after identifying the cases of discontinuity, we tried to describe how the main characteristics of governance found in the literature were distributed among the groups. Our exploratory analysis still encompassed other general characteristics found in the literature for discontinuity, aiming to improve possible inferences in this early stage of the application of the topic to credit unions.

However, the results still do not point to the importance of governance in the continuity of credit unions in Brazil. Economic aspects such as age, size and competition presented results that are more robust in this analysis. Moreover, these characteristics seem to exert influence on the governance structures investigated. For example, size and age on the model of governance, as well as the common bond on the heterogeneity of members' interests, which may require more robust governance structures. All these factors must be adequately controlled in the next steps of this study.

Another point of future analysis concerns the role of the regulatory body of the Brazilian credit unions. The actions of the CBB exert great influence over the governance of credit unions. It is relevant to question whether the $\mathrm{CBB}$ has imposed too many costs on credit unions. It would be valid to understand if this is more likely in the case of credit unions in the early stages of the life cycle. The performance of the CBB is vitally important for the maintenance of the vitality of national credit unions. Nevertheless, it is always subject to evaluation and possible corrections of course.

Despite the exploratory aspect of the research, the study still brings contributions to the area. For example, we have identified that discontinued credit unions typically have committees in their structure beyond those required by regulation. Also, we can continue the discussion about the duality and independence of boards, which involve professionalism and monitoring in cooperative organizations. In this sense, the relationships between the stages of the life cycle and the structures required at each stage of the cycle can also be decisive for the survival of credit unions. Future research can be carried out from the exploration of existing data in this work.

Some questions arise from the results. Also linked to the life-cycle theory (COOK, 1995), one may question whether discontinued credit unions in the early stages are not being forced to create governance structures larger than they support. Also, rural credit unions are changing to free entry. This migration may enrich future research by helping to understand the role of member heterogeneity in the decision to discontinue the credit union. In theory, heterogeneity must be accompanied by better corporate governance so that the organization can survive. Finally, the 
comparison between regions becomes interesting in showing how credit unions at different stages of development and competition with other financial institutions opt for their continuity.

We intend to explore in future analyses the relations and specificities found between the governance characteristics of cooperatives and other topics highlighted as determinants of the survival of organizations. In addition to deepening the exploratory analysis to further the discussion, we intend to strengthen econometric models to effectively test the relationship.

\section{Endnotes}

1 It is important to consider the possibility of a member maintaining his condition as a member and client in other banks. We do not consider a service or product of banks and credit unions as a perfect substitute.

2 There are, at least, three Brazilian cooperative systems: SICREDI, SICOOB, and CONFESOL.

SICREDI and SICOOB are bank owners. That is, each of them has a cooperative bank.

3 Our data points out 81 rural credit unions that opened their common bond between the years 2008 and 2017, becoming free entry cooperatives. Despite this, further analysis is needed to point out which have discontinued is this process.

4 An early analysis made using the common bond points out that there are no significant differences for the presence of other committees in discontinued credit unions with free entry or some type of bond.

5 Krause, Semadeni, and Cannella (2014) synthesize the research in this area. The authors point to the importance of culture, environment, and regulation in the research of duality. For credit unions, common bonds, the regulation of the $\mathrm{BCB}$ and the competition with commercial banks appear as important aspects to be considered.

\section{References}

ADAMS, R. B.; HERMALIN, B. E.; WEISBACH, M. S. The role of boards of directors in corporate governance: A conceptual framework and survey. Journal of Economic Literature, v. 48, n. 1, p. 58107, 2010.

AGHION, P.; TIROLE, J. Formal and real authority in organizations. Journal of Political Economy, v. 105, n. 1, p. 1-29, 1997.

AGHION, P.; DEWATRIPONT, M.; REY, P. Transferable control. Journal of the European Economic Association, v. 2, n. 1, p. 115-138, 2004.

ALCHIAN, A. A.; DEMSETZ, H. Production, information costs, and economic organization. The American Economic Review, v. 62, n. 5, p. 777-795, 1972.

BCB - BANCO CENTRAL DO BRASIL. Monthly data update. Retrieved from http://www.bcb.gov.br/?EVOLUTIONMONTH. Accessed in 31 jan. 2019.

BCB - BANCO CENTRAL DO BRASIL. Selected information on supervised institutions - IF.data. Retrieved from <https://www3.bcb.gov.br/informes/relatorios?lingua=en>. Accessed in 31 jan. 2019.

BARRON, D. N.; WEST, E.; HANNAN, M. T. A time to grow and a time to die: Growth and mortality of credit unions in New York City, 1914-1990. American Journal of Sociology, v. 100, n. 2, p. 381-421, 1994.

BAUER, K. J.; MILES, L. L.; NISHIKAWA, T. The effect of mergers on credit union performance. Journal of Banking \& Finance, v. 33, n. 12, p. 2267-2274, 2009. 
BECHT, M.; BOLTON, P.; RÖELL, A. Corporate governance and control. In: CONSTANTINIDES, G., M.; HARRIS, M.; STULZ, R.M. (eds.). Handbook of the Economics of Finance: Corporate finance (vol. 1A, cap. 1, pp. 1-109). Amsterdam: Elsevier, 2003.

BHAGAT, S.; BOLTON, B. Corporate governance and firm performance. Journal of Corporate Finance, v. 14, n. 3, p. 257-273, 2008.

BRICKLEY, J. A.; COLES, J. L.; JARRELL, G. Leadership structure: Separating the CEO and chairman of the board. Journal of Corporate Finance, v. 3, n. 3, p. 189-220, 1997.

BUSSAB, W. O.; MORETTIN, P. A. Estatística Básica. 9a. ed. São Paulo: Saraiva. 2017. 576 p.

CANASSA, B. J.; COSTA, D. R. M. Ciclo de vida das cooperativas de crédito brasileiras: O desempenho da cooperativa como motivo para a descontinuidade das operações. Revista de Gestão e Organizações Cooperativas. Especial, p. 51-68, 2018.

CARVALHO, F. L.; DIAZ, M. D. M.; BIALOSKORSKI NETO, S.; KALATZIS, A. E. G. Exit and failure of credit unions in Brazil: A risk analysis. Revista Contabilidade \& Finanças, v. 26, n. 67, p. 70-84, 2015.

CHADDAD, F. R.; COOK, M. L. Understanding new cooperative models: An ownership-control rights typology. Applied Economic Perspectives and Policy, v. 26, n. 3, p. 348-36o, 2004.

CHADDAD, F. R.; ILIOPOULOS, C. Control rights, governance, and the costs of ownership in agricultural cooperatives. Agribusiness, v. 29, n. 1, p. 3-22, 2013.

CONOVER, W. J. Practical Nonparametric Statistics. 3a. ed. New York: John Wiley \& Sons, 1999. 584 p.

COOK, M. L. The future of US agricultural cooperatives: A neo-institutional approach. American Journal of Agricultural Economics, v. 77, n. 5, p. 1153-1159, 1995.

COOK, M. L.; BURRESS, M. J. A cooperative life cycle framework. University of Missouri Working Paper Department of Agricultural Economics, 2009. Retrieved from http://departments.agri.huji.ac.il/economics/en/events/p-cook.pdf. Accessed in 19 set. 2018.

COSTA, D. R. M.; CHADDAD, F. R.; AZEVEDO, P. F. D. Separação entre propriedade e decisão de gestão nas cooperativas agropecuárias brasileiras. Revista de Economia e Sociologia Rural, v. 50, n. 2, p. 285-300, 2012.

DAILY, C. M.; DALTON, D. R. Bankruptcy and corporate governance: The impact of board composition and structure. Academy of Management Journal, v. 37, n. 6, p. 1603-1617, $1994 \mathrm{a}$.

DAILY, C. M.; DALTON, D. R. Corporate governance and the bankrupt firm: An empirical assessment. Strategic Management Journal, v. 15, n. 8, p. 643-654, $1994 \mathrm{~b}$.

DARRAT, A. F.; GRAY, S.; PARK, J. C.; WU, Y. Corporate governance and bankruptcy risk. Journal of Accounting, Auditing \& Finance, v. 31, n. 2, p. 163-202, 2016.

FAMA, E. F.; JENSEN, M. C. Separation of ownership and control. The Journal of Law and Economics, v. 26, n. 2, p. 301-325, 1983.

GOYAL, V. K.; PARK, C. W. Board leadership structure and CEO turnover. Journal of Corporate Finance, v. 8, n. 1, p. 49-66, 2002. 
HERMALIN, B. E.; WEISBACH, M. S. Endogenously chosen boards of directors and their monitoring of the CEO. American Economic Review, v. 88, n. 1, p. 96-118, 1998.

ILIOPOULOS, C. Ownership and governance in agricultural cooperatives: An update. Agricultural Economics Research Institute Working Paper Series, 2015. Retrieved from https://www.researchgate.net/profile/Constantine_Iliopoulos3/publication/274064574_Ownership_a nd_Governance_in_Agricultural_Cooperatives_An_Update/links/55132d140cf283eeo8337054/Owners hip-and-Governance-in-Agricultural-Cooperatives-An-Update.pdf?origin=publication_detail. Acessed in 16 jun. 2018.

JOSEFY, M.; HARRISON, J.; SIRMON, D.; CARNES, C. Living and dying: Synthesizing the literature on firm survival and failure across stages of development. Academy of Management Annals, v. 11, n. 2, p. 770-799, 2017.

KRAUSE, R.; SEMADENI, M.; CANNELLA JR, A. A. CEO duality: A review and research agenda. Journal of Management, v. 40, n. 1, p. 256-286, 2014.

RUBIN, G. M.; OVERSTREET JR.; G. A., BELING, P.; RAJARATNAM, K. A dynamic theory of the credit union. Annals of Operations Research, v. 205, n. 1, p. 29-53, 2013.

RYAN, B.; SCAPENS, R. W.; THEOBALD, M. Research Method and Methodology in Finance and Accounting. 2a. ed. Boston: Cengage Learning, 2002. 243 p.

SOARES, G. E. C. S.; COSTA, D. R. M. Mergers and acquisitions in the financial system of Brazilian credit unions. In: 2018 International Cooperative Alliance Conference, Wageningen. Abstracts... 2018 ICA Conference, 2018.

SUNDARAMURTHY, C.; LEWIS, M. Control and collaboration: Paradoxes of governance. Academy of Management Review, v. 28, n. 3, p. 397-415, 2003.

WANG, T.; HSU, C. Board composition and operational risk events of financial institutions. Journal of Banking \& Finance, v. 37, n. 6, p. 2042-2051, 2013.

WILSON, N.; WRIGHT, M.; SCHOLES, L. Family business survival and the role of boards. Entrepreneurship Theory and Practice, v. 37, n. 6, p. 1369-1389, 2013 